BULLETIN OF PNRPU. GEOLOGY. OIL \& GAS ENGINEERING \& MINING

ВЕСТНИК ПНИПУ. ГЕОЛОГИЯ. НЕФТЕГАЗОВОЕ И ГОРНОЕ ДЕ

ISSN 2224-9923

Volume/TOM 15 №21 2016

http://vestnik.pstu.ru/geo/

УДК 621.87

Article / Статья

(C) PNRPU / ПНИПУ, 2016

\title{
UPDATED ANALYSIS AND MINIMIZATION OF DYNAMIC LOADS IN ELASTIC ELEMENTS OF LIFTING EQUIPMENT
}

\section{V.S. Loveikin, lu.V. Chovniuk, I.A. Kadykalo}

National University of Life and Environmental Sciences of Ukraine (12v Geroev Oborony str., Kiev, 03127, Ukraine)

\section{УТОЧНЕННЫЙ АНАЛИЗ И МИНИМИЗАЦИЯ ДИНАМИЧЕСКИХ НАГРУЗОК В УПРУГИХ ЭЛЕМЕНТАХ ГРУЗОПОДЪЕМНЫХ МАШИН}

\section{В.С. Ловейкин, Ю.В. Човнюк, И.А. Кадыкало}

Национальный университет биоресурсов и природопользования Украины (03127, Украина, г. Киев, ул. Героев Обороны, 12в)

Received / Получена: 19.07.2016. Accepted / Принята: 31.10.2016. Published / Опубликована: 02.12.2016

\section{Keywords:}

update, analysis, minimization,

dynamic loads, elastic elements,

lifting machines, ropes,

movement modes, "hanging",

"with pickup", lifting.

\begin{abstract}
Dynamic loads regularities in elastic elements of the load-lifting machines were analyzed, in conditions of actual use they should be minimized.

An updated analysis of dynamic loads in crane ropes was conducted and conditions of loads minimization were determined. Modes of load movement on elastic rope of lifting crane were substantiated. In these modes dynamic factor KD minimizes and drive mechanism performs optimum movements. At the same time methods of classical variational calculus and apparatus of differential equations (ordinary) were used, and the calculations were carried out for two classic ways of load lifting ("hanging" and "with pickup").

The updated dynamic analysis was conducted and loads that arise in elastic elements (ropes) of lifting equipment were minimized within the two-mass model. At the same time methods of load lifting "hanging" and "with pickup" were considered for various possible modes of drive mechanism motion in the starting area.

Models for load lifting "hanging" and "with pickup" which minimizes the dynamic loads in the rope of the crane in its launching period $\left(t \in\left[0, t_{\mathrm{p}}\right]\right)$ were justified.

The results obtained can later be used to update and improve existing engineering methods for movement mode's calculation of lifting cranes and their components (when lifting is "hanging" or "with pickup"), these modes minimize the rope load at optimal modes of drive motion as at the design (construction) stage of such systems, as well during their real operation.
\end{abstract}

Ключевые слова:

уточнение, анализ,

минимизация, динамические нагрузки, упругие элементы, грузоподъемные машины, канаты, режимы движения, «с веса», «с подхватом», подъем.

\begin{abstract}
Исследованы закономерности развития динамических нагрузок в упругих элементах грузоподъемных машин, которые в условиях реальной эксплуатации необходимо минимизировать.

Проведен уточненный анализ динамических нагрузок в канатах кранов и определены условия, при которых они могут быть минимизированы.

Обоснованы режимы движения груза на упругом канате грузоподъемного крана, при которых минимизируется коэффициент динамичности $K_{\text {д }}$, а приводной механизм осуществляет при этом оптимальные движения. При этом использованы методы классического вариационного исчисления и аппарат дифференциальных уравнений (обыкновенных), а расчеты осуществлены для двух классических способов подъема груза (с веса и с подхватом). Проведен уточненный динамический анализ и минимизированы нагрузки, которые возникают в упругих элементах (канатах) грузоподъемных машин, в рамках двухмассовой модели. При этом рассмотрены способы подъема груза с веса и с подхватом для различных возможных режимов движения приводного механизма на участке пуска.

Обоснованы модели подъема груза с веса и с подхватом, которые минимизируют динамические нагрузки в канате грузоподъемного крана, в период его пуска $\left(t \in\left[0, t_{\mathrm{p}}\right]\right)$.

Полученные в работе результаты могут в дальнейшем быть использованы для уточнения и совершенствования существующих инженерных методов расчета режимов движения грузоподъемных кранов и их элементов (при подъеме с веса или с подхватом), которые минимизируют нагрузку в канатах при оптимальных режимах движения привода как на стадиях проектирования (конструирования) подобных систем, так и в режимах их реальной эксплуатации
\end{abstract}

\footnotetext{
Viacheslav S. Loveikin - Doctor of Technical Science, Professor, Head of the Department of Machinery and Equipment Construction, Vice President of the Ukrainian Academy of Lifting-Transport Sciences (tel.: 04452787 34, e-mail: lovvs@ukr.net).

Iurii V. Chovniuk - PhD of Technical Sciences, Associate Professor at the Department of Machinery and Equipment Construction, Academician of the Ukrainian Academy of Lifting-Transport Sciences (tel.: 04452787 34, e-mail: ychovnyuk@ukr.net).

Ivan A. Kadykalo - postgraduate student at the Department of Machinery and Equipment Construction (tel.: 044 527 87 34, e-mail: kadykaloivan@nubip.edu.ua). The contact person for correspondence.

Ловейкин Вячеслав Сергеевич - доктор технических наук, профессор, заведующий кафедрой конструирования машин и оборудования, вице-президент Подъемно-транспортной академии наук Украины (тел.: 04452787 34, e-mail: lovvs@ukr.net).

Човнюк Юрий Васильевич - кандидат технических наук, доцент кафедры конструирования машин и оборудования, академик Подъемно-транспортной академии наук Украины (тел.: 04452787 34, e-mail: ychovnyuk@ukr.net).

Кадыкало Иван Александрович - аспирант кафедры конструирования машин и оборудования (тел.: 04452787 34, e-mail: kadykaloivan@nubip.edu.ua). Контактное лицо для переписки.
} 


\section{The problem formulation}

It is known [1-5] that the dynamic loads in elastic elements of flexible working parts (eg ropes) in the lifting equipment drive and metal structures significantly affect their efficiency, functional reliability. Moreover, the accuracy and implementation by these machines different unloading, loading, transport and assembly operations depends on these loads essentially. It should be noted that the value of dynamic loads is a function of the lifting movement mechanism area or the entire machine. Especially significant overloads occur in transients areas (in particular during starting, braking, and reversing movement). Therefore, the problem of minimizing dynamic loads in lifting equipment elastic elements (ropes) is relevant and requires in-depth comprehensive study to deal with it.

\section{Publications analysis on the research subject}

Many works, in particular [1-25] are dedicated to study the problem of minimizing dynamic loads in lifting equipment elastic elements (ropes). Thus, the author of [4] states that braking during load descent dynamic coefficient $\left(K_{\mathrm{d}}\right)$ in crane mechanisms rope may exceed 2.5 .

There is a choice of necessary motion modes to drive mechanisms transient areas to reduce these stresses [2]. In [3] the dynamic loads in lifting equipment elastic elements minimization was carried out, which is based on the use of special motion modes actuators [2], can significantly reduce the coefficient of dynamic $K_{\mathrm{d}}$. However, in this study of the cranes ropes loads minimization is carried out on the basis of other system movement quality criteria, which uses the movement of the drive modes proposed in [2], and at the same time minimizes the actual $K_{\mathrm{d}}$.

\section{The main research content}

On the scheme of the lifting mechanism dynamic model (Fig. 1) "hanging" the following symbols are accepted: $T_{1}, T_{2}$ - reduced to the lifting rope weight respectively of the drive mechanism with the drum and the load; $x_{1}, x_{2}-$ generalized coordinates, respectively, of the masses $\mathrm{m}_{1}$ and $\mathrm{m}_{1} ; F_{2}$ - weight of the load, $F_{2}=m_{2} g ; g-$ free fall acceleration; $F_{1}-$ the moving force of the drive (and $F_{1}$, and $F_{2}$ are reduced to a load rope); $C$ - the stiffness of the rope.

The equations of the considering load lifting mechanism model "hanging" motion look [3] as follows:

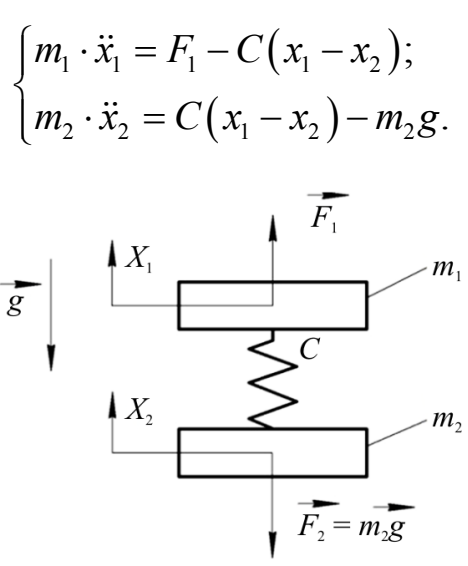

Fig. 1. A dynamic model of the crane lifting mechanism "hanging"

The system (1) can easily be reduced to a single fourth-order differential equation for $x_{2}$ :

$$
x_{2}^{(\mathrm{IV})}+k^{2} \cdot \ddot{x}_{2}=k^{2} \cdot a,
$$

where $k$ - the natural frequency of the selected lifting mechanism dynamic model "hanging", $k=\left\{C\left(\frac{1}{m_{1}}+\frac{1}{m_{2}}\right)\right\}^{\frac{1}{2}} ; a-$ the drive mechanism movement mode acceleration function, which is depended on time $t$ is shown in [2, 3], $a=a(t)$. Equation (2) is obtained taking into account the fact that the moving force of the drive is determined by the dependence $F_{1}=F_{2}+\left(m_{1}+m_{2}\right) a=m_{2} g+\left(m_{1}+m_{2}\right) a$.

The solution (2) depends on the type of the right side determined by drive mechanism motion mode $[2,3]$. In these studies the following possible drive mechanism movement modes at the starting area are considered: 1) motion with constant acceleration mode, which minimizes the value of a drive moving torque: $a(t)=a_{1}=\frac{V_{\mathrm{s}}}{t_{\mathrm{a}}}=$ const, where $V_{\mathrm{s}}$ - speed of steady load movement during lifting; $t_{\mathrm{a}}-$ load acceleration duration; 2) ramp acceleration motion mode minimizes the dynamic component of the drive power: $\left.a(t)=a_{2}(t)=\frac{2 V_{\mathrm{s}}}{t_{\mathrm{a}}}\left(1-\frac{t}{t_{\mathrm{a}}}\right) ; 3\right)$ the motion mode with acceleration change on the third order curve: $\left.a(t)=a_{3}(t)=\frac{12 V_{\mathrm{s}}}{t_{\mathrm{a}}}\left(\frac{t}{t_{\mathrm{a}}}-2 \frac{t^{2}}{t_{\mathrm{a}}^{2}}+\frac{t^{3}}{t_{\mathrm{a}}^{3}}\right) ; 4\right)$ the motion mode with change acceleration on the fifth-order curve: $a(t)=a_{4}(t)==\frac{60 V_{\mathrm{s}}}{t_{\mathrm{a}}}\left(1-\frac{t}{t_{\mathrm{a}}}\right)^{3} \frac{t^{2}}{t_{\mathrm{a}}^{2}}$. The last 
two drive motion modes provide smooth driving mechanism acceleration change for vibrations reduction of dynamic loads in the crane elastic elements (ropes).

The criterion of the system's motion quality is the following:

$$
\int_{0}^{t_{\mathrm{p}}} K_{\mathrm{d}}^{2}(t) d t \rightarrow \min ,
$$

where $K_{\mathrm{d}}=\frac{C\left(x_{1}-x_{2}\right)}{m_{2} g}=\frac{m_{2} \ddot{x}_{2}+m_{2} g}{m_{2} g}=1+\frac{\ddot{x}_{2}}{g}$.

In this case, the $K_{\mathrm{d}}$ value was obtained from the second equation of the system (1). If the criterion (3) is used with (4), we obtain

$$
\int_{0}^{t_{\mathrm{p}}}\left\{1+\frac{\ddot{x}_{2}}{g}\right\}^{2} d t \rightarrow \min .
$$

Using the the classical variations calculus apparatus, it is easy to determine the necessary condition for the implementation of criterion (5) in the form of Euler-Poisson equations:

$$
x_{2}^{(\mathrm{IV})}=0 .
$$

If we compare (6) with a more general equation of the system motion (2), we obtain

$\left\{\begin{array}{l}x_{2}^{(\mathrm{IV})}=0 ; \\ x_{2}^{(\mathrm{IV})}+k^{2} \ddot{x}_{2}=k^{2} a(t) ;\end{array} \Rightarrow \ddot{x}_{2}=a(t) ; \Rightarrow \ddot{a}(t) \equiv 0\right.$.

Then the equation for $K_{d}(\mathrm{t})$ takes the form

$$
K_{\mathrm{d}}(t)=1+\frac{a(t)}{g} .
$$

The minimum value of $K_{d}$ will be determined only by function $a(t)$ :

$$
\int_{0}^{t_{\mathrm{p}}}\left[K_{\mathrm{d}}(t)\right]^{2} d t \rightarrow \min \Rightarrow \int_{0}^{t_{\mathrm{p}}}\left[1+\frac{a(t)}{g}\right]^{2} d t \rightarrow \min .
$$

However, in this study authors opinion, this approach does not provide during the smallest value as the the basis of (7), the following relation should hold for a $(t)$, which is valid only for the first and second drive mechanism motion modes. Therefore the second equation system (1) and the first should be used in setting motion type quality criterion (5), ie it is necessary to express $\ddot{x}_{2}$ through $a(t)$ and $x_{2}^{(\mathrm{IV})}$ from equation (2), which describes all the features of system motion. So, we have with (2) and (5)

$$
\begin{aligned}
& \int_{0}^{t_{\mathrm{p}}}\left[1+\frac{1}{g}\left(\frac{k^{2} a(t)-x_{2}^{(\mathrm{IV})}}{k^{2}}\right)\right]^{2} d t= \\
= & \int_{0}^{t_{\mathrm{p}}}\left[1+\frac{a(t)}{g}-\frac{x_{2}^{(\mathrm{IV})}}{g k^{2}}\right]^{2} d t \Rightarrow \min .
\end{aligned}
$$

A necessary condition for the implementation of (10) - motion criterion of quality - is the EulerPoisson:

$$
x_{2}^{(\mathrm{VIII})}=k^{2} \cdot a^{(\mathrm{IV})} .
$$

For the first, second and third drive mechanism motion modes $(i=(1.3))$ we have: $a^{(\mathrm{IV})}(t) \equiv 0$. Only for the fourth mode $a^{(\mathrm{IV})}(t)=\frac{60 V_{\mathrm{y}}}{t_{\mathrm{p}}^{5}}\left\{72-120 \frac{t}{t_{\mathrm{p}}}\right\}$.

To solve (11) the appropriate the initial conditions must be set:

$$
\left\{\begin{array}{l}
\left.x_{2}\right|_{t=0}=0 ;\left.\dot{x}_{2}\right|_{t=0}=0 ;\left.\ddot{x}_{2}\right|_{t=0}=0 \\
\left.\dddot{x}_{2}\right|_{t=0}=0 ;\left.x_{2}^{(\mathrm{IV})}\right|_{t=0}=k^{2} a(0) ; \\
\left.x_{2}^{(\mathrm{V})}\right|_{t=0}=k^{2} \dot{a}(0) ;\left.x_{2}^{(\mathrm{VI})}\right|_{t=0}=k^{2} \ddot{a}(0) ; \\
\left.x_{2}^{(\mathrm{VII})}\right|_{t=0}=k^{2} \dddot{a}(0)
\end{array}\right.
$$

To find the specific values of derivatives $x_{2}(t)$ in time $(t)$ if $t=0$ it should find $a_{i}(0), \dot{a}_{i}(0), \ddot{a}_{i}(0), \dddot{a}_{i}(0)$ for $a_{i}(t), i=\overline{(1,4)}$. These values are defined by equation

$$
\left\{\begin{array}{l}
a_{1}(0)=\frac{V_{\mathrm{s}}}{t_{\mathrm{a}}} ; \dot{a}_{1}(0)=0 ; \ddot{a}_{1}(0)=0 ; \\
\dddot{a}_{1}(0)=0 ; \\
a_{2}(0)=\frac{2 V_{\mathrm{s}}}{t_{\mathrm{a}}} ; \dot{a}_{2}(0)=-\frac{2 V_{\mathrm{s}}}{t_{\mathrm{a}}^{2}} ; \ddot{a}_{2}(0)=0 ; \\
\dddot{a}_{2}(0)=0 ; \\
a_{3}(0)=0 ; \dot{a}_{3}(0)=\frac{12 V_{\mathrm{s}}}{t_{\mathrm{a}}^{2}} ; \ddot{a}_{3}(0)=-\frac{48 V_{\mathrm{s}}}{t_{\mathrm{a}}^{3}} ; \\
\dddot{a}_{3}(0)=\frac{72 V_{\mathrm{s}}}{t_{\mathrm{a}}^{4}} ; \\
a_{4}(0)=0 ; \dot{a}_{4}(0)=0 ; \ddot{a}_{4}(0)=\frac{120 V_{\mathrm{s}}}{t_{\mathrm{a}}^{3}} ; \\
\dddot{a}_{4}(0)=-\frac{1080 V_{\mathrm{s}}}{t_{\mathrm{a}}^{4}} .
\end{array}\right.
$$


To solve the equation (11) with initial conditions (12) for the drive motion modes $i=\overline{(1,3)}$, the following formula is used $x_{2}^{(i)}(t)$ :

$$
\begin{aligned}
& x_{2}^{(i)}(t)=\alpha_{0}^{(i)}+\alpha_{1}^{(i)} \cdot t+\alpha_{2}^{(i)} \cdot t^{2}+\alpha_{3}^{(i)} \cdot t^{3}+ \\
& +\alpha_{4}^{(i)} \cdot t^{4}+\alpha_{5}^{(i)} \cdot t^{5}+\alpha_{6}^{(i)} \cdot t^{6}+\alpha_{7}^{(i)} \cdot t^{7},
\end{aligned}
$$

where $i=\overline{(1,3)}$. Taking into account the conditions (12) the equation (17) are substantially simplified:

$$
x_{2}^{(i)}(t)=\alpha_{4}^{(i)} \cdot t^{4}+\alpha_{5}^{(i)} \cdot t^{5}+\alpha_{6}^{(i)} \cdot t^{6}+\alpha_{7}^{(i)} \cdot t^{7} i=\overline{(1,3)} .
$$

Wherein

$$
\left\{\begin{array}{l}
\alpha_{4}^{(1)}=\frac{k^{2}}{4 !} \frac{V_{\mathrm{s}}}{t_{\mathrm{a}}} ; \alpha_{5}^{(1)}=0 ; \alpha_{6}^{(1)}=0 ; \alpha_{7}^{(1)}=0 ; \\
\alpha_{4}^{(2)}=\frac{k^{2}}{4 !}\left(\frac{2 V_{\mathrm{s}}}{t_{\mathrm{a}}}\right) ; \alpha_{5}^{(2)}=\frac{k^{2}}{5 !}\left(-\frac{2 V_{\mathrm{y}}}{t_{\mathrm{p}}^{2}}\right) ; \\
\alpha_{6}^{(2)}=0 ; \alpha_{7}^{(2)}=0 ; \\
\alpha_{4}^{(3)}=0 ; \alpha_{5}^{(3)}=\frac{k^{2}}{5 !}\left(-\frac{12 V_{\mathrm{s}}}{t_{\mathrm{a}}^{2}}\right) ; \\
\alpha_{6}^{(2)}=\frac{k^{2}}{6 !}\left(-\frac{48 V_{\mathrm{s}}}{t_{\mathrm{a}}^{3}}\right) ; \alpha_{7}^{(3)}=\frac{k^{2}}{7 !}\left(\frac{72 V_{\mathrm{s}}}{t_{\mathrm{a}}^{4}}\right) .
\end{array}\right.
$$

For the mode $x_{2}^{(4)}(t) \quad(i=4)$ the solution (11) takes the form

where

$$
\begin{gathered}
x_{2}^{(4)}(t)=\alpha_{4}^{(4)} \cdot t^{4}+\alpha_{5}^{(4)} \cdot t^{5}+\alpha_{6}^{(4)} \cdot t^{6}+ \\
+\alpha_{7}^{(4)} \cdot t^{7}+\alpha_{8}^{(4)} \cdot t^{8}+\alpha_{9}^{(4)} \cdot t^{9},
\end{gathered}
$$

$$
\left\{\begin{array}{l}
\alpha_{8}^{(4)}=\frac{k^{2} \cdot 4320 \cdot V_{\mathrm{s}}}{8 ! t_{\mathrm{a}}^{5}} ; \\
\alpha_{9}^{(4)}=-\frac{7200 \cdot V_{\mathrm{s}} \cdot k^{2}}{9 ! t_{\mathrm{a}}^{6}} ; \\
\alpha_{4}^{(4)}=0 ; \alpha_{5}^{(4)}=0 ; \alpha_{6}^{(4)}=\frac{k^{2} \cdot 120 \cdot V_{\mathrm{s}}}{6 ! t_{\mathrm{a}}^{3}} ; \\
\alpha_{7}^{(4)}=\frac{k^{2}\left(-1080 \cdot V_{\mathrm{s}}\right)}{7 ! t_{\mathrm{a}}^{4}} .
\end{array}\right.
$$

Representing the obtained results in the free form:

$$
\left\{\begin{array}{l}
x_{2}^{(1)}(t)=\frac{k^{2} \cdot V_{\mathrm{s}} \cdot t^{4}}{4 ! \cdot t_{\mathrm{a}}} ; x_{2}^{(2)}(t)=\frac{k^{2} V_{\mathrm{s}}}{12 t_{\mathrm{a}}} \cdot t^{4}-\frac{k^{2} V_{\mathrm{s}} \cdot t^{5}}{60 t_{\mathrm{a}}^{2}} \\
x_{2}^{(3)}(t)=\frac{k^{2} \cdot V_{\mathrm{s}} \cdot t^{5}}{10 t_{\mathrm{a}}^{2}}-\frac{k^{2} \cdot V_{\mathrm{s}} \cdot t^{6}}{15 t_{\mathrm{a}}^{3}}+\frac{k^{2} \cdot V_{\mathrm{s}} \cdot t^{7}}{70 t_{\mathrm{a}}^{4}} \\
x_{2}^{(4)}(t)=\frac{k^{2} \cdot V_{\mathrm{s}} \cdot t^{6}}{6 \cdot t_{\mathrm{a}}^{3}}-\frac{k^{2} \cdot V_{\mathrm{s}} \cdot 3 \cdot t^{7}}{14 t_{\mathrm{a}}^{4}}+ \\
+\frac{k^{2} \cdot V_{\mathrm{s}} \cdot 3 \cdot t^{8}}{28 t_{\mathrm{a}}^{5}}-\frac{k^{2} \cdot V_{\mathrm{s}} \cdot 5 \cdot t^{9}}{252 \cdot t_{\mathrm{a}}^{6}} .
\end{array}\right.
$$

In such (22) the lifting load motion modes "hanging" on rope for all $(i=\overline{(1,4)})$ acquires its ideal (!) value, ie, $K_{\mathrm{d}}^{(i)}(t) \equiv 1$ при $t \in\left[0, t_{\mathrm{a}}\right]$.

To analyze the lifting mode "with pickup" the model that describes the process in the form of a differential equation for the rope tension force is used $F=C\left(x_{1}-x_{2}\right)$ :

$$
\begin{gathered}
\ddot{F}+k^{2} \cdot F=2 k^{2} \cdot Q+\frac{C\left(m_{1}+m_{2}\right)}{m_{1}} a_{i}(t), \\
Q=m_{2} g,
\end{gathered}
$$

with the initial conditions

$$
t=0 ; F=0 ; \dot{F}=C \cdot V_{\mathrm{s}} .
$$

The condition (24) corresponds to a situation that lifting load "with pickup" at the initial moment the rope strain is zero (since the the load weight is perceived by base), but given the drive weight $\left(m_{1}\right)$ in the process of choosing a rope weakness has a speed $\left(V_{s}\right)$ substantially equal to the nominal or close to it [1].

The dynamic factor $K_{\mathrm{d}}^{(i)}(t)$ if $i=\overline{(1,4)}$ for all variants within the actuator motion model (23) has the form

$$
K_{\mathrm{d}}^{(i)}(t)=2+\frac{\left\{\frac{C\left(m_{1}+m_{2}\right)}{m_{1}} a_{i}(t)-\ddot{F}\right\}}{\left(k^{2} \cdot m_{2} g\right)} .
$$

For lifting mode "hanging" initial conditions (23) takes the following form:

$$
t=0 ; \quad F=Q=m_{2} g ; \dot{F}=0 .
$$

There are dependences $F(t)$ and $K_{\mathrm{d}}^{(i)}(t)$ for all $i=\overline{(1,4)}$ drive motion modes on the Fig. 2. The analysis shows that there are significant oscillations of $F(t)$ and $K_{\mathrm{d}}^{(i)}(t)$ during $t \in\left[0, t_{\mathrm{a}}\right]$. Graphics have oscillating characteristic for each ith drive motion mode ("hanging" and "with pickup").

Let us consider further the conditions of load lifting ("hanging" or "with pickup") the following quality motion criterion is implemented:

$$
I=\int_{0}^{t_{\mathrm{p}}}\left\{K_{\mathrm{d}}^{(i)}(t)\right\}^{2} d t \rightarrow \min .
$$

A necessary condition for this criterion implementation is the Euler-Poisson equation, which takes the form in the model (23) 

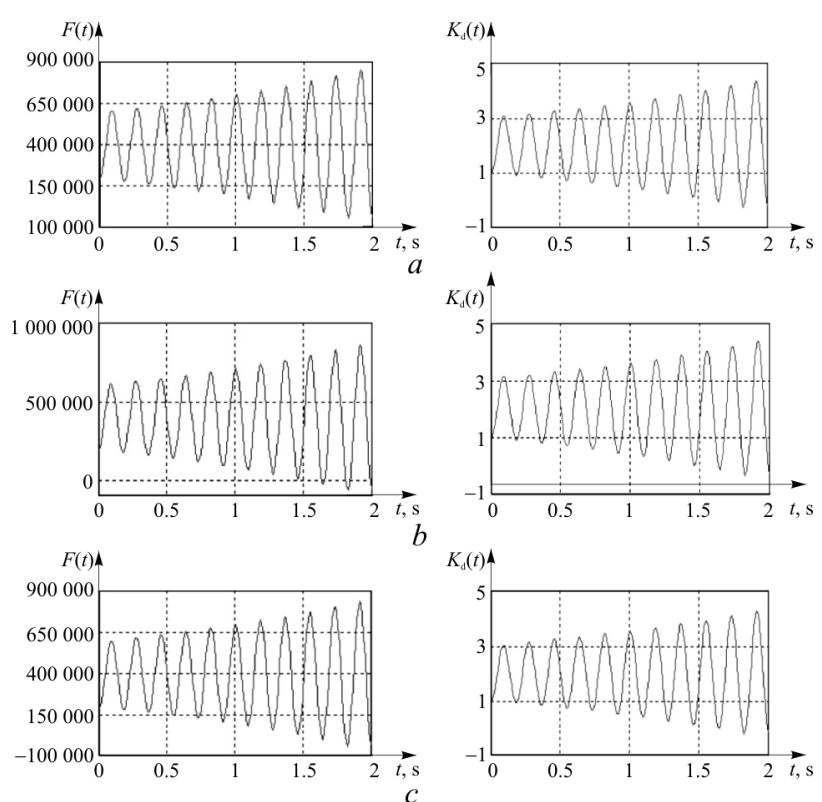

$b$

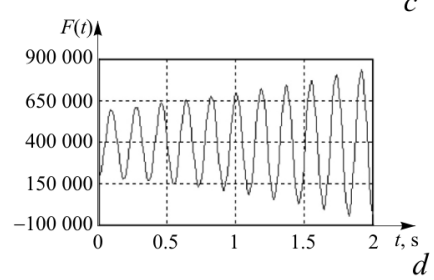

C $K_{d}(t)$
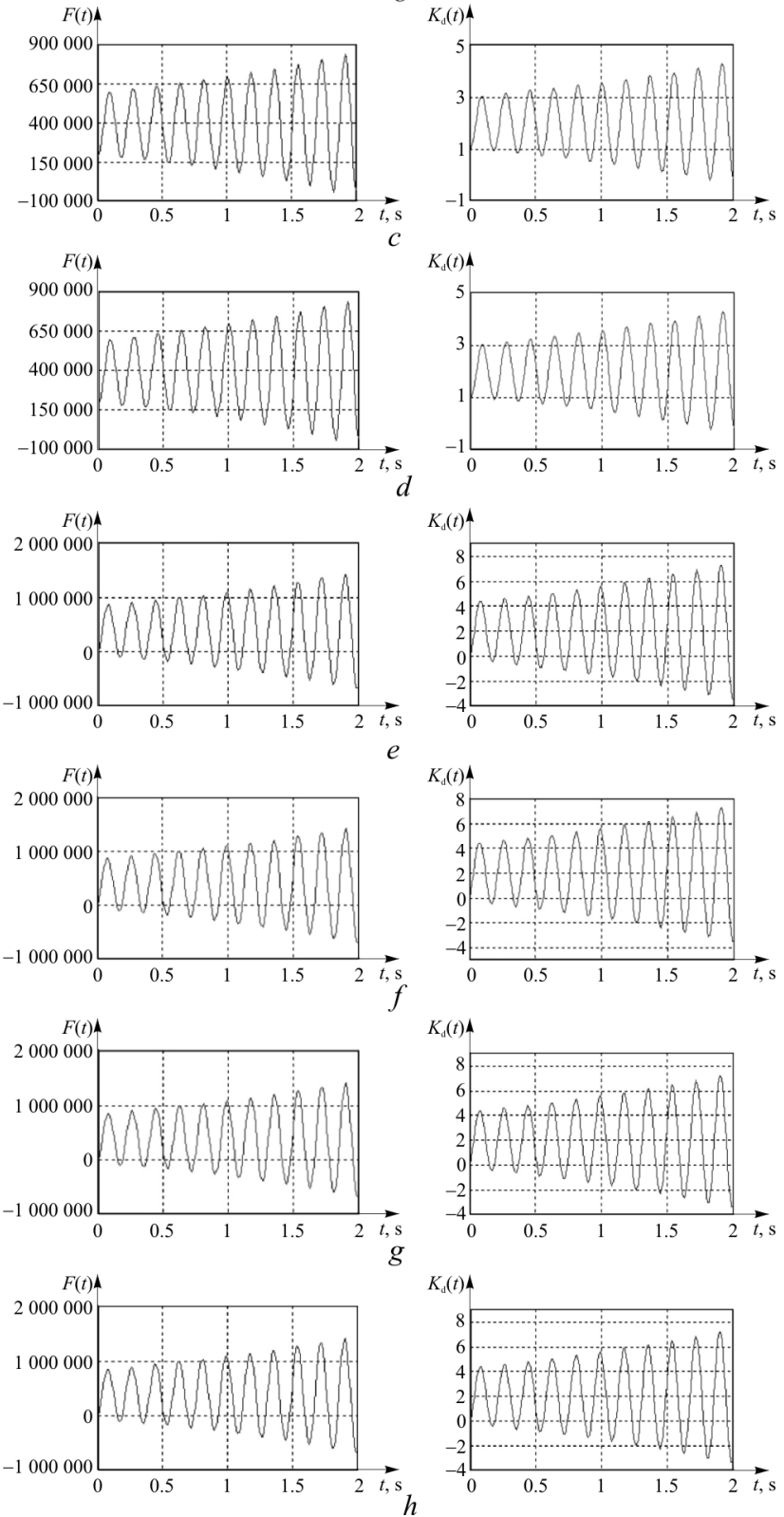

$K_{d}(t)$

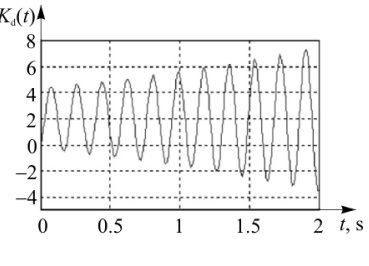

$K_{\mathrm{d}}(t)$
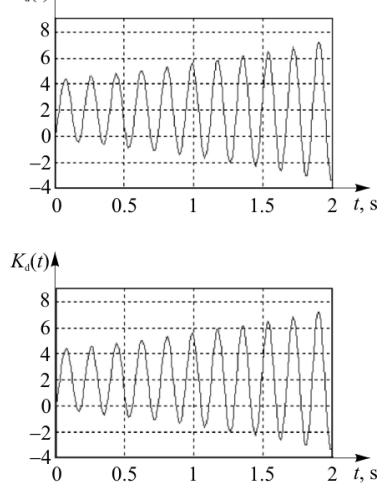

Fig. 2. Dependencies $F(t)$ and $K_{\mathrm{d}}^{(i)}(t)$ for all $i=\overline{(1,4)}$ drive motion modes: $a-d-$ "hanging"; $e-h-$ "with pick up"
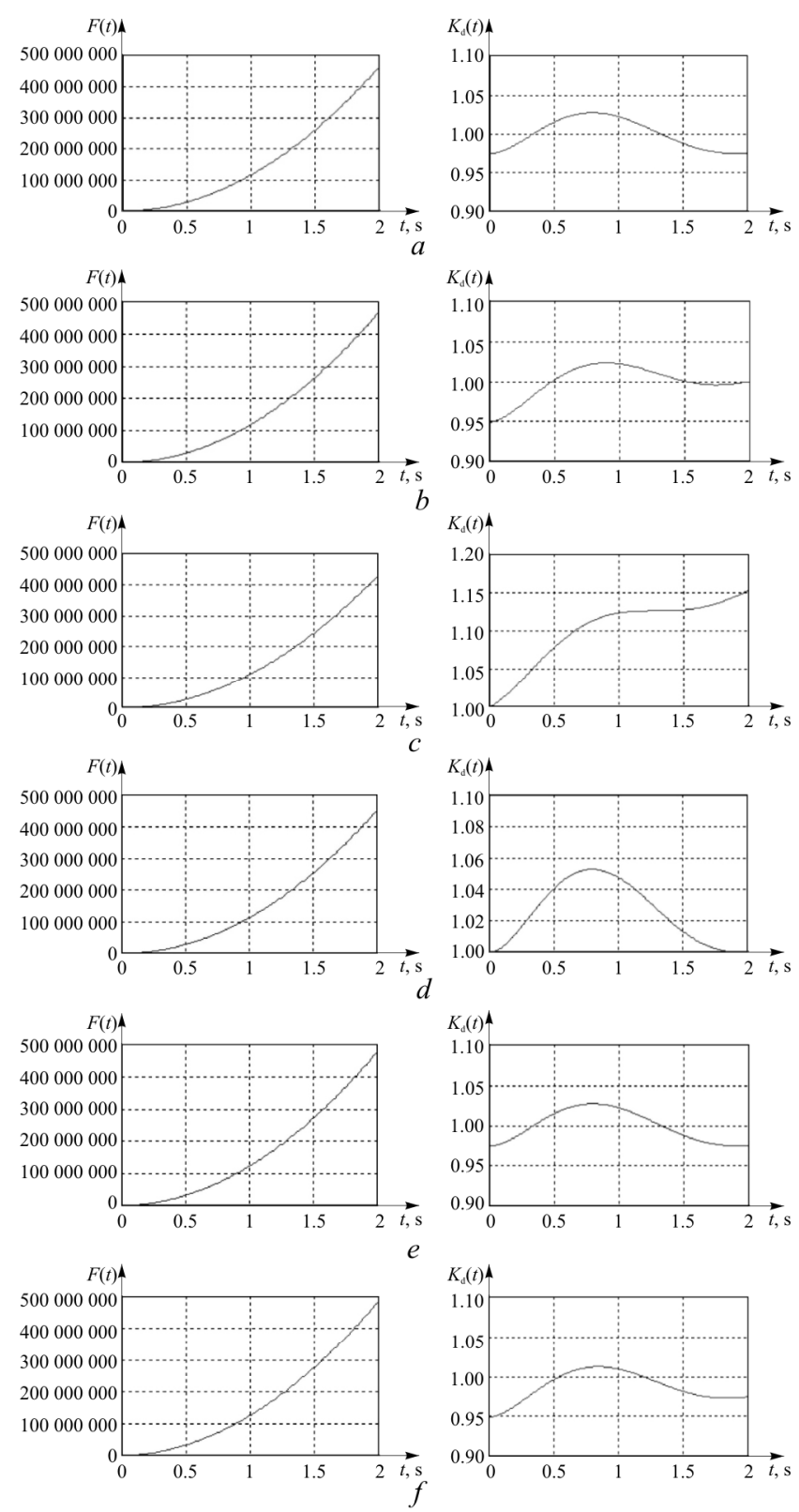

$e$
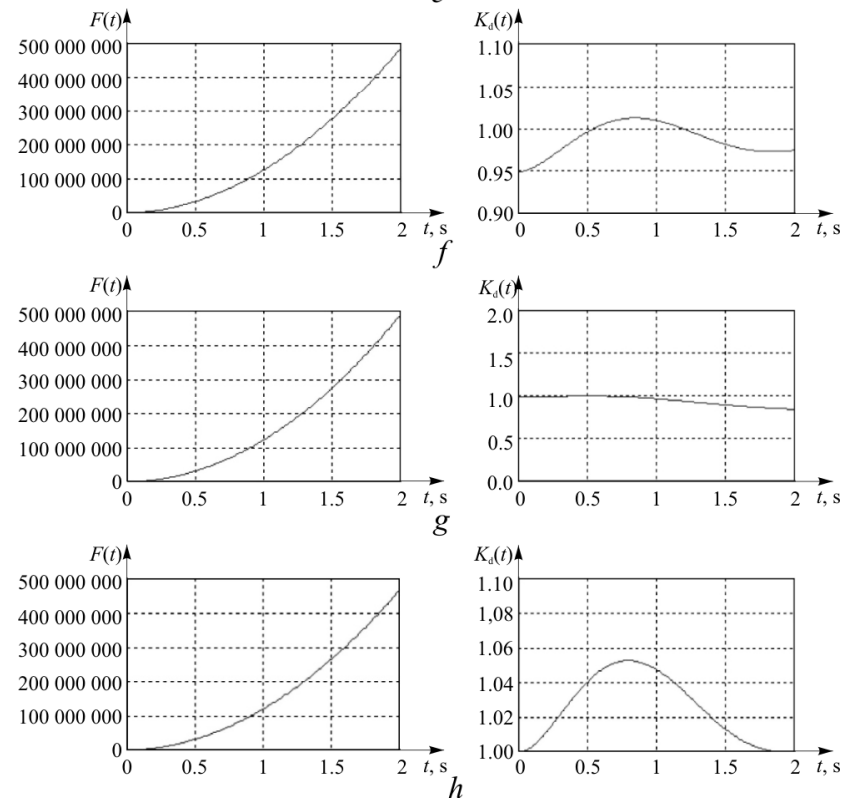

Fig. 3. Dependencies $F(t)$ and $K_{\mathrm{d}}^{(i)}(t)$ for all $i=\overline{(1,4)}$ drive motion modes: $a-d-$-hanging"; $e-h-$ "with pick up" 


$$
F^{(\mathrm{IV})}=\frac{C\left(m_{1}+m_{2}\right)}{m_{1}} \ddot{a}_{i}(t)
$$

The initial conditions for lifting " hanging" for (28) have the form

$$
\left\{\begin{array}{l}
t=0 ; F=Q=m_{2} g ; \dot{F}=0 ; \\
\ddot{F}=k^{2} \cdot Q+\frac{C\left(m_{1}+m_{2}\right)}{m_{1}} a_{i}(0) ; \\
\dddot{F}=\frac{C\left(m_{1}+m_{2}\right)}{m_{1}} \dot{a}_{i}(0) .
\end{array}\right.
$$

The initial conditions for lifting "with pickup" for (28) have the form:

$$
\left\{\begin{array}{l}
t=0 ; F=0 ; \dot{F}=C \cdot V_{\mathrm{y}} ; \\
\ddot{F}=k^{2} \cdot Q+\frac{C\left(m_{1}+m_{2}\right)}{m_{1}} a_{i}(0) ; \\
\dddot{F}=\frac{C\left(m_{1}+m_{2}\right)}{m_{1}} \dot{a}_{i}(0) .
\end{array}\right.
$$

To carry out numerical calculations on the computer the following parameters values of load crane lifting mechanism were used [3]: $C=1.545 \cdot 10^{7} \mathrm{H} / \mathrm{m} ; g=9.81 \mathrm{~m} / \mathrm{s}^{2} ; m_{l}=41550 \mathrm{~kg}$; $m_{2}=20000 \mathrm{~kg} ; V_{s}=0.5 \mathrm{~m} / \mathrm{s} ; t_{a}=2.0 \mathrm{~s}$.

The values $\ddot{a}_{i}(t), \quad a_{i}(0)$ and $\dot{a}_{i}(0)$ for $i=\overline{(1,4)}$ are:

$$
\left\{\begin{array}{l}
\ddot{a}_{1}(t)=0 ; \ddot{a}_{2}(t)=0 ; \\
\ddot{a}_{3}(t)=\frac{24 V_{\mathrm{s}}}{t_{\mathrm{a}}}\left\{-\frac{2}{t_{\mathrm{a}}^{2}}+\frac{3 t}{t_{\mathrm{a}}^{3}}\right\} ; \\
\ddot{a}_{4}(t)=\frac{120 V_{\mathrm{s}}}{t_{\mathrm{a}}^{3}}\left\{1-9 \frac{t}{t_{\mathrm{a}}}+18 \frac{t^{2}}{t_{\mathrm{a}}^{2}}-10 \frac{t^{3}}{t_{\mathrm{a}}^{3}}\right\} .
\end{array}\right.
$$

\section{References}

1. Goberman L.A., Stepanian K.V., Iarkin A.A., Zelenskii V.S. Teoriia, konstruktsiia $\mathrm{i}$ raschet stroitel'nykh i dorozhnykh mashin [Theory, design and calculation of building and road machines]. Moscow: Mashinostroenie, 1979, 407 p.

2. Loveikin V.S. Raschety optimal'nykh rezhimov dvizheniia mekhanizmov stroitel'nykh mashin [Calculations of optimal movement modes of building machines' mechanisms]. Kiev: UMK VO, 1990, $166 \mathrm{p}$.

$$
\begin{gathered}
a_{1}(0)=\frac{V_{\mathrm{s}}}{t_{\mathrm{a}}} ; a_{2}(0)=\frac{2 V_{\mathrm{s}}}{t_{\mathrm{a}}} ; \\
a_{3}(0)=0 ; a_{4}(0)=0 ; \\
\dot{a}_{1}(0)=0 ; \dot{a}_{2}(0)=-\frac{2 V_{\mathrm{s}}}{t_{\mathrm{a}}^{2}} ; \\
\dot{a}_{3}(0)=\frac{12 V_{\mathrm{s}}}{t_{\mathrm{a}}^{2}} ; \dot{a}_{4}(0)=0 .
\end{gathered}
$$

In the model (28) for the conditions (29) or (30) (corresponding to lifting "hanging" or "with pick up") and values $\ddot{a}_{i}(t)(31), a_{i}(0)(32), \dot{a}_{i}(0)$ (33) calculations of $F(t)$ and $K_{\mathrm{d}}^{(i)}(t)$ were held if $t$ change in $\left[0 ; t_{a}\right]$

Analysis of the shown in Fig. 3 graphs, for the functions $F(t)$ and $K_{\mathrm{d}}^{(i)}(t)$ shows that the model (28) and the corresponding initial conditions for the force $F$ and its derivatives $\dot{F}, \ddot{F}, \ddot{F}$, the values of $\ddot{a}_{i}(t)$ (31), $a_{i}(0)$ (32), $\dot{a}_{i}(0)$ (33) graphs characteristic $F(t)$ are not oscillatory (only monotonous, growing in time), and $K_{\mathrm{d}}^{(i)}(t)$ for $i=(1,4)$ to lifting "hanging" or "with pick up" during $t \in\left[0, t_{\mathrm{a}}\right]$ practically corresponds to the "ideal" load lifting $\left(K_{\mathrm{d}}^{(i)}(t) \rightarrow 1, t \in\left[0, t_{\mathrm{a}}\right]\right)$.

\section{Conclusions and suggestions}

1. The loads lifting models "hanging" and "with pickup", which minimize the crane rope dynamic forces in its start period $\left(t \in\left[0, t_{\mathrm{a}}\right]\right)$ were proved.

2. The obtained results later can be used to update and improve existing engineering methods for calculating the cranes motion modes and their components (lifting "hanging" or "with pickup") which minimize the ropes load with the best drive motionmodes (in terms of the results of [2]) as at the such systems design stage and the modes of their actual operation.

3. Loveikin V.S. Minimizatsiia dinamicheskikh nagruzok v uprugikh elementakh gruzopod"emnykh mashin [Minimizing dynamic loads in elastic elements of lifting equipment]. Gornye, stroitel'nye, dorozhnye $i$ meliorativnye mashiny. Kiev, 1998, vol.52, pp.63-68.

4. Kozhevnikov S.N. Dinamika nestatsionarnykh protsessov $\mathrm{v}$ mashinakh [The dynamics of nonstationary processes in machines]. Kiev: Naukova dumka, 1986, $288 \mathrm{p}$. 
5. Volkov D.P. Dinamicheskie nagruzki v universal'nykh ekskavatorakh-kranakh [Dynamic loads in universal excavators-cranes]. Moscow: Mashgiz, 1958, $269 \mathrm{p}$.

6. Zommerfel'd A. Mekhanika [Mechanics]. Moscow: TIIL, 1947, 392 p.

7. Aleksandrov M.P. Pod"emno-transportnye mashiny [Lifting and transport machines]. Moscow: Vysshaia shkola, 1985, $520 \mathrm{p}$.

8. Vaison A.A. Pod"emno-transportnye mashiny [Lifting and transport machines]. Moscow: Mashinostroenie, 1989, 536 p.

9. Gaidamaka V.F. Gruzopod"emnye mashiny [Lifting machines]. Kiev: Vysshaia shkola, 1989, $326 \mathrm{p}$.

10. Aleksandrov M.P., Kolobov Ia.N., Lobov N.A. et al. Gruzopod"emnye mashiny [Lifting machines]. Moscow: Mashinostroenie, 1986, 400 p.

11. Krasnikov V.V., Dubinin Z.F., Akimov V.F. et al. Pod"emno-transportnye mashiny [Lifting and transport machines]. Moscow: Agropromizdat, $1987,272 \mathrm{p}$.

12. Maron F.L., Kuz'min A.V. Spravochnik po raschetam mekhanizmov pod"emno-transportnykh mashin [Manual for mechanisms calculations in lifting and transport machines]. Minsk: Vysshaia shkola, 1977, $270 \mathrm{p}$.

13. Pravila ustroistva i bezopasnoi ekspluatatsii gruzopod"emnykh kranov [Rules for arrangement and safe operation of lifting cranes]. Moscow: Metallurgiia, 1981, $168 \mathrm{p}$.

14. Raschet kranovykh mekhanizmov i ikh detalei [Calculation of crane mechanisms and their parts]. Moscow: Mashinostroenie, 1971, $495 \mathrm{p}$.

15. Zubko N.F. Prognozirovanie koeffitsientov dinamichnosti v elementakh kranovykh mekhaniz- mov [Prediction of dynamic factors in the crane mechanisms elements]. Vestnik Odesskogo natsional'nogo morskogo universiteta, 2013, no.2 38), pp.63-71.

16. Dietrich M. Dynamic von Kranen bei plötzlichem lastabfall. Hebezeuge und Fördermittel, 1964, no.4, pp.362-364.

17. Dietrich M. O dynamice hamowania dSwignic. Arch. Bud. Masz. Warszawa, 1965, vol. 12, z. 2, pp.261-281.

18. Dietrich M. Statistische analyse der dynamik beim kranfahren. Wissen. 2. T.U. Dresden, 18, H I, pp.223-225.

19. Dresig H. Ermittlung dynamischer belastungen an wippdrehkranen: dissertation, T.H. Dresden, 1965, 203 p.

20. Dresig H. Massenkräfte in kranen beim anheben der last. Hebezeuge und Fördermittel, 1967, vol. 1, s. 13-16, no.2, pp.38-42.

21. Dresig H. Massenkräfte beim drehen von doppellenkerkranen. Hebezeuge und Fördermittel, 1968, 18, pp.225-230.

22. Eiler P. Uber massenkräfte an dreh-und wippenkranen: dissertation, T.H. München, 1966, $246 \mathrm{p}$.

23. Ernst L. Dimensionieren von hebezeugen auf der grundlage des betriebsfestigkeitsnachweises der TGL 13470; Ausgabe 10.74. Hebezeuge und Fördermittel, 1976, no.1, pp.14-17.

24. Fetizon F., Jouannet J.G., Yatremetz M. Tower crane in turbulent wind. Pract. Exper. Flow-induced Vibr. Symp., Karlsruhe, 1978. Berlin, 1980, p. 760-765.

25. Fiegehen E.G. The standardization of crane essentials. The Engineer, 1925, no. 3623, p. 7-11; no. 3649 , p. 8-9.

\section{Список литературы}

1. Теория, конструкция и расчет строительных и дорожных машин / Л.А. Гоберман, К.В. Степанян, А.А. Яркин, В.С. Зеленский. М.: Машиностроение, 1979. - 407 с.

2. Ловейкин В.C. Расчеты оптимальных режимов движения механизмов строительных машин. - Киев: УМК ВО, 1990. - 166 с.

3. Ловейкин В.С. Минимизация динамических нагрузок в упругих элементах грузоподъемных машин // Горные, строительные, дорожные и мелиоративные машины. - Киев, 1998. - Вип.52. - С. 63-68.
4. Кожевников С.Н. Динамика нестационарных процессов в машинах. - Киев: Наукова думка, 1986. -288 с.

5. Волков Д.П. Динамические нагрузки в универсальных экскаваторах-кранах. - М.: Машгиз, 1958. - 269 с.

6. Зоммерфельд А. Механика. - М.: ТИИЛ, 1947. $-392 \mathrm{c}$.

7. Александров М.П. Подъемно-транспортные машины. - М.: Высшая школа, 1985. - 520 с.

8. Вайсон А.А. Подъёмно-транспортные машины. - М.: Машиностроение, 1989. - 536 с. 
9. Гайдамака В.Ф. Грузоподъемные машины. Киев: Высшая школа. Головное изд-во, 1989. - 326 с.

10. Грузоподъемные машины / М.П. Александров, Я.Н. Колобов, Н.А. Лобов [и др.]. М.: Машиностроение, 1986. - 400 с.

11. Подъёмно-транспортные машины / В.В. Красников, З.Ф. Дубинин, В.Ф. Акимов [и др.]. - М.: Агропромиздат, 1987. - 272 с.

12. Марон Ф.Л., Кузьмин А.В. Справочник по расчетам механизмов подъемно-транспортных машин. - Минск: Высшая школа, 1977. - 270 с.

13. Правила устройства и безопасной эксплуатации грузоподъемных кранов. - М.: Металлургия, 1981. - 168 с.

14. Расчет крановых механизмов и их деталей / ВНИИПТМаш. - М.: Машиностроение, 1971.-495 с.

15. Зубко Н.Ф. Прогнозирование коэффициентов динамичности в элементах крановых механизмов // Вестник Одесского национального морского университета. - 2013. - № 2 (38). - С. 63-71.

16. Dietrich M. Dynamic von kranen bei plötzlichem lastabfall // Hebezeuge und Fördermittel. - 1964. - № 4. - S. 362-364.

17. Dietrich M. O dynamice hamowania dSwignic // Arch. Bud. Masz. - Warszawa, 1965. - Vol. 12, z. 2. - S. 261-281.
18. Dietrich M. Statistische analyse der dynamik beim kranfahren. Wissen. 2. T.U. Dresden, 1969. - 18, H I. - S. 223-225.

19. Dresig H. Ermittlung dynamischer belastungen an wippdrehkranen: dissertation, T.H. Dresden, 1965. - $203 \mathrm{~s}$.

20. Dresig H. Massenkräfte in kranen beim anheben der last // Hebezeuge und Fördermittel. 1967. - Vol. 1. - S. 13-16; № 2. - S. 38-42.

21. Dresig H. Massenkräfte beim drehen von doppellenkerkranen // Hebezeuge und Fördermittel. - 1968. - 18. - S. 225-230.

22. Eiler P. Uber massenkräfte an dreh-und wippenkranen: dissertation, T.H. - München, 1966. - $246 \mathrm{~s}$.

23. Ernst L. Dimensionieren von hebezeugen auf der grundlage des betriebsfestigkeitsnachweises der TGL 13470; Ausgabe 10.74 // Hebezeuge und Fördermittel. - 1976. - № 1. - S. 14-17.

24. Fetizon F., Jouannet J.G., Yatremetz M. Tower crane in turbulent wind // Pract. Exper. Flow-induced Vibr. Symp., Karlsruhe, 1978. Berlin: 1980. - P. 760-765.

25. Fiegehen E.G. The standardization of crane essentials // The Engineer. - 1925. - № 3623. - P. 7 11; № 3649. - P. 8-9.

Please cite this article in English as:

Loveikin V.S., Chovniuk Iu.V., Kadykalo I.A. Updated analysis and minimization of dynamic loads in elastic elements of lifting equipment. Bulletin of PNRPU. Geology. Oil \& Gas Engineering \& Mining, 2016, vol.15, no.21, pp.354-361. DOI: 10.15593/2224-9923/2016.21.7

Просьба ссылаться на эту статью в русскоязычных источниках следующим образом:

Ловейкин В.С., Човнюк Ю.В., Кадыкало И.А. Уточненный анализ и минимизация динамических нагрузок в упругих элементах грузоподъемных машин // Вестник Пермского национального исследовательского политехнического университета. Геология. Нефтегазовое и горное дело. - 2016. - Т.15, №21. - C.354-361. DOI: 10.15593/2224-9923/2016.21.7 